\title{
STRATEGIES FOR DEVELOPING RELIGIOUS CULTURE TO SHAPE, THE CHARACTER OF STUDENTS
}

Muslimah Hikmah Wening', Enung Hasanah²

1,2. Ahmad Dahlan University, Postgraduate, Yogyakarta, Indonesia

Email: 'muslimahhikmah55@gmail.com

\begin{abstract}
Religious culture is applied in schools so that the good habits of students, so that the strategy of developing religious culture is essential to be applied to schools so that students have a noble character in Islamic education. The purpose of this study is to describe the strategy of developing a religious culture to shape students' character. This research is qualitative. Data collection obtained through in-depth interviews, observation, and documentation studies. This study's subject was determined based on a purposive sampling technique with information from the homeroom teacher. Checking the validity of the data starts with using a check and continues with the triangulation technique. The results showed that the strategy of developing a culture of religious and improving the character of students at SD Muhammadiyah Tonggalan, 1) creating a religious atmosphere in schools including allocating half an hour to learn to read the Qur'an before the lesson begins, do the Dhuha, Dhuhr, Asr prayer, Ramadan fasting, qurban worship, hajj rituals, social services, Sunday morning teachings, also (2) habituation of Islamic values. The research findings expected to illustrate that the strategy of developing religious culture can shape students' character.
\end{abstract}

Keywords: strategy, development, religious culture, character.

\section{INTRODUCTION}

The rapid development of technology, information, and technology has further strengthened the effects of globalization on human behavior. Globalization also involves significant changes in social life, culture, politics, and education of the world into adherents who are neo-liberal and capitalist (Wani, 2011). Various impacts that often encountered are the effects of the rapid progress of information so that it can know throughout the world, with the internet all easy to find from the knowledge and insight quickly get the information we need. The impact of globalization is not only in the field of technology, there are many other impacts, not only with its advantages but also with its shortcomings, as is currently happening in Indonesia.

Five main areas are affected by globalization: economic globalization, globalization of information/communication technology, political globalization, business globalization, and education globalization (Alli, Winter, \& May 2011). The five things do not affect human behavior in the world, including the behavior of young Indonesian people who ideally hold fast to eastern culture. However, instead, many are interested in culture from the outside, which is not necessarily compatible with the environment of Indonesian society. 
The current condition of young people is very alarming. Various cases of immorality, violence, and a decline in understanding of social norms, shows how weak the defense of the nation's cultural character in filtering global cultural currents. The situation needs to be sought for a solution so that moral degradations do not occur that are prolonged, one of which is by inculcating religious values since childhood. Religious values that are identical to moral education in religion are the foundation of the concept and implementation of character education (Sukardi, 2016).

The development of religious culture in schools is a way to develop religious values in schools as a foothold of values, enthusiasm, attitudes, and behavior for school residents. In the implementation of religious culture, the school has a solid foundation, normative, and constitutional so that the school cannot avoid the effort that has build. The implementation of religious culture should be exemplary and implemented at all levels of school because religious and cultural values instilled in students can strengthen their faith and applied in the school environment. Though the religious culture of schools that often done can make the character of students walk. Cultures that do at school can make students understand how good habits are carried out and can be applied to shape their character to be better. Therefore, the strategy for developing a religious culture to shape the character of students is essential to study.

Character education is how someone's effort to do consciously and planned to educate and empower a potential student to build his character. The role of schools assisted by teachers in building character in the learning process is an effort to shape student character (Marini, 2017). According to (Siswati, Utomo, and Muntholib 2018)the implementation of character education cannot be separated from the functions and objectives of national education In Law No. 20 of 2003 which reads: national education functions to develop capabilities and shape the character and character of the nation's civilization, aiming at developing the potential of participants educate them to become human beings who believe in God Almighty, noble, healthy, knowledgeable, capable, creative, independent, and become citizens who are democratic and responsible.

SD Muhammadiyah Tonggalan is one of the schools in Klaten and has just implemented istisqa, an attempt to instill religious culture to improve the Islamic character of its students. It is following the vision and mission of creating a generation of pious, faithful and pious, cultured, and Islamic characters in the environment. Based on the description above, researchers are interested in knowing the implementation and what programs are 
implemented at SD Muhammadiyah Tonggalan to form a religious culture to improve their students' Islamic character. Therefore a study entitled "Strategic Development of Religious Culture to Shape the Character of Students. Referring to the description above, the formulation of the problem that is the main focus of this study is "How is the strategy of developing a religious culture to shape the character of students. Based on the formulation of the problem at hand, the researchers set the goal to describe the development of religious culture to shape students' character at SD Muhammadiyah Tonggalan.

With the disclosure of religious culture development strategies to shape students' character, they become a reference for other school principals and teachers and education practitioners in applying religious culture in their respective schools, as a reinforcement of student character education efforts in the present. School culture and culture significantly influence the school management system that will shape the school's vision, mission, and goals. It expects graduate students to influence people's lives and government expectations so that education can realize its full potential. This research's theoretical contribution expects to be able to enrich the analysis of practice or theory about religious culture in the formation of character in schools.

\section{METHODS}

The purpose of this study is to describe the strategy of developing a religious culture to shape the character of students. It is a qualitative based on the fundamental idea that "reality" is subjective: every human being constructs an individual, personal view of the world based on his specific interactions with the outside world (Cropley, 2015). The researchers collected data collection techniques through 3 ways of interviewing, observing, and documenting-data analysis techniques using the theory of Miles and Hubermen with data triangulation. The subjects of this study consisted of PAl teachers and class teachers.

\section{RESULTS}

The interviews showed that all religious activities carried out to achieve the vision, mission, and goals of the school, namely the creation of a generation of shooleh, believers and pious with the creation of an Islamic school to realize a fun culture-based learning and character education. Morning activity greeting and handshaking this activity is carried out every day before entering the school gate by scheduling the picket teacher. So before entering the classroom, there is a picket teacher who does this activity every morning. Likewise, students also make greetings and handshakes to their teachers and friends. Morning Quran, this activity is carried out every day before carrying out learning activities in the 
classroom. The material given is biased according to memorization to achieved in the class. Friday morning, recitation conducted every Friday.

Formation of dhuha and dhuhr prayers in congregation, Dhuha prayer activities in togetherness has been done and scheduled by the school, as well as the same time prayers for the first grade who can pray at their accompaniment and taught slowly to perform prayers. As for the Asr prayer in congregation is done for 6th-grade students who have tutored at school. Ramadhan Cottage held every fasting month. It expected that by doing this activity, students could interpret what the virtues of the month of Ramadan are. Sacrificial worship activities at the Muhammadiyah Elementary School in Tonggalan held every month of Dhulhijah. The school held a joint prayer in the morning and then sacrificed qurban animals and usually distributed them to the residents. Hajj Ritualcarried out to provide knowledge and hands-on practice in the field with guidance to implement the fifth pillar of Islam. This social service does give sadaqah to the people who are less able to get closer to God so that what we ask for inshallah is granted. Sunday Morning Teaching: This activity is carried out every sunday morning and scheduled for which classes will take part. The activity is coordinating by the school and the teacher who will accompany him later in school.
Based on the data that can be collected, it can identify that planting religious values in SD Muhammadiyah Tonggalan can be seen in tabel. As follows:

Table 1.Religious values developed at SD Muhammadiyah Tonggalan

\begin{tabular}{|c|c|}
\hline Activity & Developed Value \\
\hline $\begin{array}{l}\text { Salam dan jabat } \\
\text { tangan }\end{array}$ & $\begin{array}{ll}\text { Religious } & \text { and } \\
\text { discipline } & \end{array}$ \\
\hline Morning Qur'an & $\begin{array}{l}\text { Religious, honest, } \\
\text { courage, discipline, } \\
\text { firm stance and } \\
\text { istiqomah }\end{array}$ \\
\hline $\begin{array}{l}\text { Performing prayer } \\
\text { in congregation }\end{array}$ & $\begin{array}{l}\text { Religious, } \\
\text { discipline, } \\
\text { cleanliness, } \\
\text { responsibility, } \\
\text { courage. }\end{array}$ \\
\hline $\begin{array}{l}\text { Ramadhan } \\
\text { Cottage }\end{array}$ & $\begin{array}{l}\text { Religious, honest, } \\
\text { disciplined, patient, } \\
\text { and competing in } \\
\text { goodness. }\end{array}$ \\
\hline $\begin{array}{l}\text { Qurban Worship } \\
\text { Hajj Ritual }\end{array}$ & $\begin{array}{l}\text { Religious, generous, } \\
\text { sincere, willing to } \\
\text { sacrifice, and } \\
\text { empathy } \\
\text { responsibility, } \\
\text { discipline, } \\
\text { courage }\end{array}$ \\
\hline Social Service & $\begin{array}{l}\text { Religious, generous, } \\
\text { willing to sacrifice, } \\
\text { persistent and never } \\
\text { give up }\end{array}$ \\
\hline $\begin{array}{l}\text { Sunday Morning } \\
\text { Teaching }\end{array}$ & $\begin{array}{l}\text { Religious, generous, } \\
\text { willing to sacrifice, } \\
\text { caring, and sincere }\end{array}$ \\
\hline
\end{tabular}




\section{DISCUSSION}

The results showed that some programs carried out at SD Muhammadiyah Tonggalan in the religious culture development program at school to shape the character of students tended to emphasize the religious attitude culture. The program shows that the character to be achieved is religious. Religious-based character education is carried out daily with environmental conditioning and habituation methods (Cinantya, Suriansyah, and Asniwati 2018). By doing it every day, it hopes that they can get useful knowledge for them later. The programs that have implemented at SD Muhammadiyah Tonggalan are as follows:

a. Greeting s and handshaking

The religious culture that is often practiced at school every day will have a good impact on students. In this activity, students expected to be able to form good characters through the emphasis on universal values to all students (Adams 2011). Efforts made deliberately by the school expected to foster a friendly character towards teachers and friends, religious in Islamic learning among Muslims greeting each other, and discipline to conduct greetings before entering class. The process of character building is fundamental, especially during childhood, and is carried out at school (Althof and Berkowitz 2006). With this activity, students can improve their behavior (Anugerah Ash-shidiqqi, 2018). These habits are also expected by the teacher to foster good character so that students do not fall into the wrong directions.

b. Morning Qur'an

The form of activities carried out in the morning before starting learning is the morning Qur'an. This activity carried out so that students get positive behavior in the classroom (Wagner and Ruch 2015). It is the inculcation of teachings in daily life (Noh et al. 2014). the activity conducted by the class teacher and carried out about 30 minutes before the lesson begins Qur'an learning effective intervention is carried out in the morning (El-Hady and Kandeel 2017). Each class has different achievements, such as grades 1-3, which refers to the memorization of short surah and grades 4-6, which refers to the memorization of the long surah. The activity carried out in order to instill religious-based character education in the sense of practicing Islamic teachings. Such as being honest in the extent to which they have memorized, to be brave, discipline, firm in their stance and istiqomah according to the table of values for the development of student character in SD Muhammadiyah Tonggalan. Encourage students to realize ethical values to put in practice for the future (Tsai 2012). So to encourage this to do this activity at school.

c. Formulation of dhuha and dhuhr prayers in congregation

This activity is taught in schools to teach them about the obligations of Muslims who perform the five daily prayers as the main pillars of the Islamic religion (Rock-Singer 
2016). Dhuha prayer done together and has scheduled by the school. As well as Dhuhr prayer at the same time, but during the second-hour break. For children who have not been able to pray, class 1 will be taught prayer by the class teacher and will accompany. Students taught prayer until they can do it themselves. Ashar Prayers are usually performed by grade 6 students who take part in the activities of tutors at school. This activity is to foster the character of religious students who carry out religious orders. Honest in doing prayer five times at home or school. Discipline carries out divine commands that have taught at school. Love cleanliness before doing shola tapa has to do with cleanliness so that it can apply to other fields. Responsibility for his religion what he ordered. Courageous in this study, students who can be taught as prayer priests. Accordance with the expected religious assessment table at the school because character education is the deliberate attempt to influence the behavior of students through repeatedly customizing (Abu 2015).

\section{d. Ramadhan Cottage}

This Ramadhan hut carried out every fasting month. This activity carried out to train students to understand what are the virtues of the month of Ramadan. There are benefits gained in this activity, especially to train students to be more patient. So that various activities of students can understand the struggle of the Prophets and Prophets who have brought Islam to us by interpreting the commemoration of other Islamic holidays (Suyitno 2018). The inculcation of character to be achieved by the school is a religious, honest, disciplined, patient, and competing in kindness by the table expected to inculcate religious values.

\section{e. Qurban Worship}

SD Muhammadiyah Tonggalan conducts qurban worship activities at school. Eid alAdha and tasriq days as a form of aqarrub or closer to Allah (Abdullah 2016). This activity is carried out after the Eid al-Adha prayer to slaughter qurban animals at school. After finishing slaughtering the meat that distributed to residents. It is to foster characters for students who are religious, generous, sincere, willing to sacrifice, and empathy so that they can improve the behavior of students (Anugerah Ash-shidiqqi 2018).

f. Hajj Ritual

Hajj rituals are carried out by schools to provide students with knowledge about knowledge and practice directly in the field with the guidance of teachers so that if they carry out the fifth pillar of Islam. Likewise, increasing confidence in equality and harmony between ethnic groups coincides with other schools (Clingingsmith, Khwaja, and Kremer 2009). The inculcation of character to be achieved in this program is religious, honest, sincere, willing to sacrifice, responsibility, discipline, and courage

g. Social Service The social service that the student gives sadaqah to poor people. This strategy was also applied to make the students be 
able to distinguish between good and bad character traits (Putri, Harto, and Moecharam 2017). With learning to distinguish good and bad to do good for the surrounding community and their place of residence. The character to be achieved according to the table of religious values that will apply at the school. The characters to achieve in this activity are religious, generous, willing to sacrifice, persistent, and never give up to improve student education behavior (Anugerah Ash-shidiqqi 2018).

h. Sunday Morning Teaching

This activity is carried out every Sunday morning and has scheduled for which classes will take part in. This activity coordinated by the school and the teacher who will accompany him later in school. The characters to achieve in this activity are religious, generous, willing to sacrifice, care, and sincere in order to improve student education behavior (Anugerah Ash-shidiqqi 2018).

The habit that carried out every day will have a good impact on students. This habituation is essential to do in religious culture with the habituation of students by practicing both individual and in groups. The teacher is also accommodating in habituating religious culture through classroom programs. The development of religious culture in schools can be done by and programmed by the school. The teacher determines building school power because it is the first person the students will emulate. However, not only are teachers who are the spearhead for building school culture but all school members (Mulyasa and Aryani 2017).

\section{CONCLUSION}

The results revealed that developing a religious culture to enhance the character of students at SD Muhammadiyah Tonggalan was carried out holistically, through routine programs, carried out by all stakeholders consistently. Besides, the support of facilities and infrastructure also has a stake in the sustainability and success of character education based on religious values.

\section{ACKNOWLEDGMENTS}

Thank the supervising lecturers, PAI teacher, and classroom teacher without the help from them. This article cannot finish.

\section{REFERENCES}

Abdullah, Mulyana. 2016. "Qurban: Wujud Kedekatan Seorang Hamba Dengan Tuhannya." Jurnal Pendidikan Agama Islam-Ta'lim 14(1): 109-16.

Abu, Lukman. 2015. "How to Develop Character Education of Madrassa Students in Indonesia." journal of Education and Learning. Vol. 8(4) pp. 369-376 9: 79-86.

Adams, Abigail. 2011. "The Need for Character Education." International Journal of Social Sciences and Humanity Studies 3(2): 23-32.

Althof, Wolfgang, and Marvin W. Berkowitz. 2006. "Moral Education and Character Education: Their Relationship and Roles in Citizenship Education." Journal of Moral 
Education 35(4): 495-518.

Alli, Ali \& Winter, Gregory \& May, David. (2011). Globalization: Its Effects. International Business \& Economics Research Journal (IBER). 6. 10.19030/iber.v6il.3339.

Anugerah Ash-shidiqqi, Ellectrananda. 2018. "The Analysis of Character Education in Indonesia." International Journal of Humanities, Art, and Social Studies (IJHAS) 3(4): 39-46.

Cinantya, Celia, Ahmad Suriansyah, and A. Asniwati. 2018. "The Model of Religion-Based Character Education (Multi-Site Integrated Islamic Paud Sabilal Muhtadain and Paud Islam Mawaddah Banjarmasin, Indonesia)." European Journal of Education Studies 5(7): 1-13. https://oapub.org/edu/index.php/ej es/article/view/2097/4733.

Clingingsmith, David, Asim ljaz Khwaja, and Michael Kremer. 2009. "Estimating the Impact of the Hajj: Religion and Tolerance in Islam's Global Gathering." Quarterly Journal of Economics 124(3): 1133-70.

Cropley, Arthur. (2015). Introduction to Qualitative Research Methods.

El-Hady, Mona Mohamed, and Nahed Attia Kandeel. 2017. "The Effect of Listening to the Qur'an on Physiological Responses of Mechanically Ventilated Muslim Patients." IOSR Journal of Nursing and Health Science 6(5): 2320-1940. www.iosrjournals.org.

Marini, Arita. 2017. "Character Building Through Teaching-Learning Process: Lesson in Indonesia." PONTE International Scientific Research Journal 73(5).

Mulyasa, H E, and Wiwik Dyah Aryani. 2017. "Developing Religious Culture In School." International Journal of Scientific \& Technology Research 06(07): 263-67.

Noh, Mohd Aderi Che, Ab Halim Tamuri,
Khadijah Abd Razak, and Asmawati Suhid. 2014. "The Study of Quranic Teaching and Learning: United Kingdom Experience." Mediterranean Journal of Social Sciences 5(16): 313-17.

Putri, Mentari Antika, Sri Harto, and Nicke Yunita Moecharam. 2017. "Promoting Character Education in EFL Classroom: Using Children ' $S$ Literature As a Teaching Material." Journal of English and Education 5(2): $\quad$ 163-69. http://ejournal.upi.edu/index.php/LE/article/view/9946\%0APROMOTING.

Rock-Singer, Aaron. 2016. "Prayer and the Islamic Revival: A Timely Challenge." International Journal of Middle East Studies 48(2): 293-312.

Siswati, Siswati, Cahyo Budi Utomo, and Abdul Muntholib. 2018. "Implementasi Pendidikan Karakter Dalam Membentuk Sikap Dan Perilaku Sosial Peserta Didik Melalui Pembelajaran Sejarah Di SMA PGRI 1 Pati Tahun Pelajaran 2017/2018." Indonesian Journal of History Education 6(1): 1-12. https://journal.unnes.ac.id/sju/index. php/ijhe/article/view/27332.

Sukardi, I. (2016). Character Education Based on Religious Values: An Islamic Perspective. Ta'dib: Journal of Islamic Education Volume 21, Number 1, June 2016. 41-58.

Suyitno. 2018. "Untuk Meningkatkan Karakter Islami." EDUKASI: Jurnal Pendidikan, Vol 10, No.2, 10(2): 191204.

Tsai, Kaun Chen. 2012. "Bring Character Education into the Classroom." European Journal of Educational Research 1(2): 163-70.

Wagner, Lisa, and Willibald Ruch. 2015. "Good Character at School: Positive Classroom Behavior Mediates the Link between Character Strengths and School Achievement." Frontiers in Psychology 6(MAY): 1-13.

Wani, Hilal. (2011). Impact of 
Globalization on World Culture. 2. 33-

39. 